\title{
Talsipühade sanditamised ja maskid bessermanide tänapäevases kalendrikombestikus
}

\begin{abstract}
Jelena Popova
Teesid: Artikkel käsitleb bessermanide tänapäevast talsipühade kombestikku ja maske. Jälgitakse maskeerimistavade muutumist ja kombetalituste tähtsust tänapäeva külakeskkonnas. Tähelepanu all on mütoloogilised ettekujutused talsivaimudest, ruumi ja ajaga seotud piirangud ja eelistused pühade ajal, maskeerimise eripärad ja maskid, rituaalne köök ja etikett. Viimastel aastatel on kombestik ja selle elemendid hakanud juurduma tänapäevasesse pühadekultuuri, kuid siin on täheldatav mõningate protsesside paralleelne areng: arhailisi elemente ja nende arengut mõjutab aktiivselt nüüdiskultuur.
\end{abstract}

Märksõnad: bessermanid, maskeerimine, rituaalne söömaaeg ja toidud, talsipühade kombestik, traditsioonid ja uuendused

Bessermanid (бесер, бесерман / Besermians, Besermans) on Venemaa väikerahvas, kes elab kompaktselt Udmurdimaa loodeosas. Nad räägivad udmurdi keele bessermani murret. Levinud on vene keel, aga väikestes bessermani-tatari segaasundustes ka tatari keel. Usutunnistuselt on bessermanid õigeusklikud. Venemaa 2002. aasta rahvaloenduse andmeil on bessermane 3122 (Rahvuslik koosseis 2004: 9). Viimaste aastate uuringud lubavad rääkida etnose koosseisus kahest rühmast - junda-gordino (selle rühma vanade asualade Junda ja Gordino (udm Gurjakar) asunduse järgi) rühmast, kuhu kuuluvad bessermanid Tšeptsa (udm Tšuptši) jõe keskjooksul (praeguse Udmurtia Balezino ja Glazovi (udm Glaz) rajoon); ja Lekma (udm Ljukmõ), mis ühendab Tšeptsa vasakkalda lisajõgede Lekma (udm Ljukmõ), Lema (udm Ljumõ) ja Ubõti (udm Õbõt) asunduste elanikke (Jukamenskoje (udm Jukamen) ja Jari (udm Jar) rajoon). Nende rühmituste formeerumisel ilmnesid väikesed kohalikud eripärad kõnelemisviisis, pärandmuusikas ja kombestikus, sealhulgas ka talsipühade tsüklis ja maskides. Mõningane spetsiifika on seotud nii nende rühmade eripäradega kui ka kombestikuelementide transformeerumise ja konserveerumise eri astmetega. Artiklis kasutatavad materjalid on autor kogunud bessermanide asualadel sooritatud 
välitööde käigus. Peamise meetodina kasutati andmekogumisel intervjuusid, kombestiku jälgimist ja kombetalitustel osalemist. Teadusuuringuga kaasnes fotode tegemine ja videosalvestus.

Bessermanide kalendrikombestik kujutab endast tänapäeval nii pika aja jooksul tekkinud traditsiooniliste elementide kui ka viimastel aastakümnetel ilmnenud tendentside sulamit. Isegi kalendrikombestiku oluliste muutuste foonil määravad traditsioonilised ettekujutused endiselt mitmeid nähtusi tänapäeva kultuuris ja maailmavaates. See puudutab kõige tähtsamate aastalõikude markeeringut, sealhulgas suvist ja talvist pööripäeva, talsipühade maskeerimist, maske ja kombestiku struktuuri.

\section{Aasta struktuur ja mütoloogilised kujutelmad talsivaimudest}

Vaadates kõige olulisemaid uuendusi, on vaja anda üldjoontes traditsiooniline kontekst, millel kombestik ja ettekujutused põhinevad ja säilivad tänapäeva külaolustikus. Rahvamütoloogia ja ettekujutused aasta struktuurist määravad allesjäänud ajalis-ruumilised keelud, köögi, soovid, kombestiku elemendid ja selle ümber kujunenud küla jõudeaja veetmise tänapäevased vormid. Maskeerimise terminoloogia, kombestiku semantika ja selle ruumilis-ajalised parameetrid võimaldavad selgitada välja, mil määral on traditsioonilised mütoloogilised ettekujutused tänapäeva kultuuris ja maailmavaates säilinud, kahe poolaasta (sügistalvise ja kevadsuvise) vastastikuse sideme rahvapärase tõlgenduse, kalendritsüklite vahetumise ja aasta uuenemise, mis moodustavad rituaalse tegevuse aluse. Kombestik toetub endiselt ettekujutustele erilistest vaimudest vožo (udm вожо), kes mütoloogiliste seisukohtade kohaselt kaks korda aastas "ilmuvad inimeste sekka". Esimest korda pööras oma ekspeditsioonil sellisele kalendrijaotusele ja "talistetele kaks korda aastas", bessermanide eriliste "talsivaimude" olemasolule tähelepanu tuntud vene etnograaf Dmitri Zelenin (Zelenin 1910). Ettekujutus kahest poolaastast ja talistepühade kombestikust leidsid kajastamist ka bessermanide traditsioonilise kalendri uurimustes (Popova 2004).

Talsikombestikku ja -maske uurides on vaja enne ära näidata selle arusaamaringi kõige olulisemad karakteristikud. Suvist ja talvist pööripäeva, tavandit, maskeerimises osalejaid ja vaime tähistatakse ühtmoodi: vоžo (вожо). See termin ja analoogilised ettekujutused esinevad ka mõnedel udmurtide rühmadel. ${ }^{1}$ Bessermanide arvates vožo vaimud "tulevad mööda jõge, kui rukis kõrsub", "ilmuvad rukki õitsemise ajal", asuvad veekogude läheduses, külvatud põldudel, aga talvel tulevad uuesti tagasi ja lähevad tagasi "alla 
mööda jõge”: “Öeldi, et vožo läheb vee alla. Nad on nagu inimesed. Suvel vožo on teatud aja, kuid see ei ole nii range aeg nagu talvel" (AVM 1999, Z. Žuravljova, Gordino (udm Gurjakar) küla). Suvel peetakse nende aktiivseks ajaks keskpäeva, talvel hämarat aega ja ööd. Kõige lähemaid paralleele võib täheldada udmurtide, eelkõige bessermanide lähinaabrite, põhja-udmurtide religioonilis-mütoloogilistes arusaamades ja kalendrikombestikus (Vladõkin 1994: 243; Gluhhova 2009: 46).

Kombestiku detailide, kasutatavate maskide, ruumilis-ajaliste keeldude ja eelistuste ning rituaalsete toitude mõistmist soodustavad ettekujutused vožo vaimude endi kohta. Tänase päevani säilinud ja käibivate igas žanris tekstide kohaselt esinevad nad antropomorfsel kujul ning on suutelised ümber kehastuma: "valget värvi, maja või samba kõrgune inimene", "oli suur ja äkki muutus inimese kasvu”, "nagu inimesed”, "üleni valges”. Neil on isegi etniline kuuluvus: udmurdid, venelased, bessermanid. Materjalides kajastub ettekujutus nende suhetest teispoolse maailmaga, uppunutega, lahkunud esivanemate hingedega, mis väljendub ajuti lausa otsestes analoogiates. Bessermanide seas levinud ettekujutustele leidub analoogiaid jõulukommetes ja teistes kultuurides. Maskeerijate seost esivanemate kultusega on korduvalt käsitletud teaduskirjanduses, sealhulgas slaavi ainestiku põhjal (Vinogradova 1982: 147; Vinogradova \& Plotnikova 2009: 457; Ivleva 1994: 65; Tšernõhh 2007: 68-69).

Tänapäeval bessermanidelt üleskirjutatud tekstides esinevad püsivad süžeed, mis tõendavad vožo võimekust ümber kehastuda ja ilmuda aasta kõige olulisematel üleminekuaegadel:

Vožodest ei tohi halvasti rääkida. Nad näevad välja nagu inimesed. Nende seas on noori ja vanu. Vožod on surnud inimesd. Bessermanid bessermanide riietes, udmurdid udmurtide riietuses. Saabaste ja viiskudega käivad. Nendele tuleb alati meelehead valmistada. Nad on kõige kallimad - kuldsed külalised. Kõike kuulevad (AVM 1995: M. V. Sabrekova, Šamardani (tat Шәмәрдән) küla, Jukamenskoje (udm Jukamen) rajoon).

Vožod sarnanevad inimestele. Neid on nähtud. Nad ilmuvad inimestele ainult vožo ajal (AVM 1999, A. P. Žuravljova, Junda küla, Balezino rajoon).

... ja siin ilmusid vožod: peenikesed sääred valgete sokkide ja mustade sukkadega. Lähevad ja räägivad omavahel (AVM 1999, Z. I. Žuravljova, Gordino (udm Gurjakar) küla, Balezino rajoon).

Sedalaadi tekstid muutuvad aktuaalseks talistete aegu ja kõige suuremat variatiivsust võib täheldada vanema põlvkonna jutustustes. Noortel ja lastel on jutud fragmentaarsed ning nende sisu seisneb tavaliselt vanematelt kuuldud 
tekstide kordamises, võõrastelt kuuldud või oma "vožo vaimudega kohtumise" kogemuslugude ümberjutustamises. Nende "kohtumistena" tõlgendatakse tänapäeval mõnikord selliseid ebatavalisi nähtusi nagu helid või müra talsiajal, eksimised teed otsides, vankri või auto ootamatu seismajäämine, hämaruses mitteeluruumides või saunas saabunud surm või õnnetus. Teel olija hukkumise, pimeduses või öösel tee kaotamise ja haiguse põhjusena nähti sel aastaajal kehtinud ruumilis-ajaliste keeldude rikkumist. Tänapäeval osalevad paljud kombetalituses, süvenemata selle mütoloogilisse konteksti, pidades kõike traditsiooniks ja pühade meelelahutuseks. Täheldatav on aga pärimuskandjate seisukohalt erineva säilimis- ja olulisuse astmega pärimuse samaaegne käibimine, sealhulgas kehtestatud käitumisnormide järgimine, ruumiliste ja ajaliste keeldude, kombetalituses osalemise reeglitega arvestamine, rituaalsete toitude valmistamine. Paljusid talvistepüha maskeerimise elemente, mida varem täideti kogu külaga (rituaalne söömaaeg ühes tares, vožo vaimude kollektiivsed "saatmised"), viiakse nüüd läbi enamasti pereringis.

Talvistepühade ja vožo vaimudega seotud kombestikul oli maaviljeluse seisukohalt suur tähtsus. Ka tänapäeval on talvise maskeerimise atribuutides ja maskides, ruumilis-ajalistes piirangutes, soovides ja rituaalses toidus täheldatav agraarne alatoon. Kõige eredamaks ja sisutihedamaks tegevuseks on jäänud maskeeritute ringkäik külas.

Ettekujutus "suvistest" ja "talvistest vožodest" ei ole aktuaalsust kaotanud, nad on vastastikused, määravad talistetsükli tänapäevased kombetalitused ja markeerivad neid kahte perioodi aastas. Suvise pööripäeva aega kutsutakse gužem šor (гужэл шор) 'suve keskpaik' või gužem vоžo (гужэм вожо) 'suvine vožo', gerber (гербер) 'aeg pärast atra', ja sellel ajal ei ole selgeid piire. See algab juuni keskpaiku (umbes suvise pööripäeva paiku) ja kestab peetripäevani (12. juuli ukj), mitmes külas 14. augustini - meepühani (esimene Kristuse äraseletamise püha). Varem korraldati sel ajal kevadsuvise tsükli olulisi kombetalitusi: ohverdamised ja ilusa ilma palumised, pidulik söömaaeg ja võiga palvetamine põllul, naiste, oma patronüümilise ringi esindajate, aasta ainus külaskäik kultusehitisse (Popova 2004: 108-133). Suvise pööripäevaga olid seotud ranged ruumilis-ajalised keelud, mille rikkumine võis kaasa tuua ebasoodsa ilma, mõjutada saaki. Keskpäevast päikeseloojanguni ei tohtinud jões pesu loputada, ujuda, võtta metallnõusse vett, minna rukkipõllule, lärmata veekogu ääres, kasutada musti nõusid:

Gerberi ajal ei tohi lõuna ajal pesu pesta. Võib alles pärast keskpäeva kella kolme-nelja ajal. Kui seda reeglit rikkuda, peksab rahe põllul vilja maha (AVM 2000, D. I. Malõh, Žuvami küla, Jukamenskoje rajoon). 
Kui rukis kõrsub, ei tohi jões pesu loputada. Ilm läheb hukka. Müristab. Välku lööb (AVM 2000, M. V. Sabrekova, Šamardani küla, Jukamenskoje rajoon).

Keskpäeval ei minda majast välja, ei tooda allikalt vett, ei pesta pesuäike tuleb (AVM 2000, F. J. Šmeleva, Tõlõsi küla, Jukamenskoje rajoon).

Lahtistest veekogudest võeti vanasti suve sel perioodil vett ainult kasetohust anumaga või puuämbritega, hiljem, kui kasutusele tulid juba plekkämbrid, hoiti neid spetsiaalselt veevõtuks. Reeglid minetasid aktuaalsuse pärast tsükli lõppu (eeliapäevast või meepühast alates), kui "aasta pöördus juba sügisesse". See oli põlluharijale oluline aeg. Viljasaak sõltus paljudest asjaoludest, ja mütoloogiline teadvus markeeris ohu mahavõtmiseks kõiki võimalikke ohte (põud, torm, paduvihm, äike ja järsk külmenemine), mis võivad suvel tulla. Vanema põlvkonna esindajad meenutasid, et veel 1930.-1940. aastatel jälgis nendest reeglitest kinnipidamist spetsiaalne inimene, kelle hooleks oli küla suvine tuleohutus. Tal oli õigus eksinuid ka avalikult karistada. Ettekujutus suvisest tsüklist on tänapäeval säilinud mitmetes tekstides ja terminoloogias, harvemini reeglitena, millest osa inimestest endiselt kinni peab. Suve ja aasta selle ajaga seotud kombestik on juba kadunud. Suvise pööripäevaga seotud keelud ja reeglid, mida siin tutvustatud, on levinud paljudel rahvastel, kuid üldine mütoloogiline taust on kõige lähedasem udmurtidele (Vladõkina 1998: 84; Gluhhova 1999: 117; Pletneva 1999: 245-249).

Talvine periood langeb kokku talistete tsükliga ja seda nimetatakse tualte vоžo ( пуалтэ вожо, tol vožo / tolalte vožo). See kestab 6.-18. jaanarini, mõnes asunduses 6.-19. jaanuarini ${ }^{2}$ ning 13.-18. jaanuarini, ${ }^{3}$ st algab jõululaupäeval (ühel kohalikul rahvarühmal vana uusaasta), ja lõpeb "vožo ärasaatmise" talitusega 18. jaanuaril kolmekuningapäeva eelõhtul (mõnes külas kolmekuningapäeval). Erinevad tähtajad on seotud mõningaste piirkondlike erisustega ja kujunesid välja traditsioonilise kalendri raames, kuid pole tänaseni aktuaalsust kaotanud.

Talistete ajaga olid seotud ruumilis-ajalised keelud, mille rikkumine võis mõjutada viljasaaki või tuua kaasa inimese haiguse või lausa hukkumise. Näiteks katkestati vanasti viljapeks, et vožo vaimud ei rikuks suvekülvi või et neile kogemata mitte viga teha, oletades, et nad viibivad nähtamatuna kõikjal; keelatud oli labida või rauast esemetega treppi puhastada, et "neid mitte riivata"; kolmekuningapäevani peatati pesupesemine, ei loputatud pesu jääaugus ega allikal (Popova 2004). Püüti mitte astuda söe peale, kartes, et kaera tabab nõgihaigus (Zelenin 1910: 117). Samal põhjusel ei puhastatud ahjulõõre ega võetud tuhka välja. Vaatamata traditsiooni transformatsioonile püütakse jär- 
gida pesupesemise ning sauna ja tühjade ruumide külastamise keeldu õhtuti ning hoiduda hämaras teelolekust.

Erinevalt suvisest tsüklist on talvine tsükkel ka tänapäeval keerulise kombestikuga. Muidugi käibivad tänapäeval paljud ettekujutused hajusas vormis, säilitades mõningase terviklikkuse vanema põlvkonna inimeste juttudes, kuid just nemad määravad säilinud kombestiku struktuuri ja mõningad elemendid.

\section{Maskid}

Rituaalsete toitude valmistamine ja ettevalmistus maskeeritute külaskäiguks algab mõnes külas jõululaupäeval (6. jaanuar). ${ }^{4}$ Päeval küpsetatakse leiba hapendamata taignast pirukaid (sotšni), õhtupoole meisterdatakse kostüüme ja maske. Õhtuks köetakse saun, mis öeldakse olevat "määratud vožo vaimudele”, keda võetakse vastu kui kaugeid külalisi "lugupidamise ja suurte auavaldustega". Saunas käivad sel päeval kõik pereliikmed. Seda päeva kutsutakse vožo (вожо), sotšen' (сочень), sotšelnik nunal (сочельник нунал, jõululaupäev), aga 7. jaanuari juba rožvo (рожво) jõulupäevaks. Selle päeva eredaim sündmus on igas vanuses ja koosseisus maskeeritute külaskäigud. Mõnes asunduses on neid üks või kaks-kolm, mõnes viis või koguni rohkem rühma. See sõltub traditsiooni säilimise määrast konkreetses külas, elanike aktiivsusest ja rahvaarvust. Tavaliselt käiakse väikeste seltskondadena, mis moodustatakse vanuse (lapsed, teismelised, noored ja täiskasvanud), sõprus- või naabrussuhete alusel, mõnikord käiakse ka üksinda.

Ringkäigud algavad hämaruses kella kuue paiku ning kestavad õhtul kella kaheksa-üheksani, kuid mitte kauem. Järgitakse olulist reeglit, kus on jälgitav paaris- ja paaritu arvu semantiline tähendus, mis on minetanud oma olulisuse selle kombestiku teistes elementides. Näiteks osaletakse ringkäigus paaritu arv päevi - üks või kolm, mõned järgivad endiselt kommet külastada üksnes paaritut arvu maju:

Kindlasti tuleb sisse astuda kolme majja, mitte vähem. Kui nii teha, siis lähevad kõik haigused mööda. Meil vanad käivad praegu ka, aga kindlasti kolmes majas (AVM 1990, V. M. Tšibõševa, Junda küla, Balezino rajoon; AVM 2010, Junda küla).

Kombetalituses osalemist peetakse endiselt hea viljasaagi, tervise ja majandusliku edu aluseks:

Kui maskeerituid majja ei lase, hakkab koduloomadel ja inimestel halb (AVM 1995, M. V. Sabrekova, Šamardani küla, Jukamenskoje rajoon). 
Eraldi peatume maskidel tänapäeva kombestikus. Iga päev eeldab spetsiaalseid maske, nende valmistamise viis ja järjekord on oma põhiolemuselt jäänud traditsiooniliseks. Ühes asunduste rühmas käiakse esimesel päeval "hirmsate/ kurjade vožodena" (mõnikord kutsutakse seda maski karuks), pahupidi pööratud kasuka või karusnahkse mantliga, mütsiga, nägu kaetakse musta riide või marliga, kuhu on lõigatud augud silmade ja suu kohale. Riidest maski asendavad mõnikord ülestõstetud krae ja sügavale silmile tõmmatud müts. Maskeeritute kohustuslikud atribuudid on sau/kepp ja kott/seljakott/kilekott annetuste korjamiseks. Sel päeval kasutatakse ainult musta värvi (tumedaid) karusnahkseid esemeid (tulupeid, kasukaid) või joppe/palituid. Esimest päeva peetakse kõige olulisemaks ja jõulutsükli alguseks, aga vožo vaimud ja neid kehastavad maskid "nõuavad erilist lugupidamist ja austust".

Teisel päeval käiakse maskidega, mida teatakse ilusa vožona (чебер вожо) traditsioonilises värvimata lõuendist riietuses, st valdav on valge värv. Kolmandal päeval kasutavad maskeerimises osalejad maskide valmistamiseks ja riietuses punast värvi esemeid ja riideid. Varem oli see traditsiooniline bessermani riietus, valmistatud kodusel teel punasest ja bordoovärvi lõuendist ja kirjust (triibulisest või ruudulisest) riidest. Vahel harva tehti zoomorfseid maske, peamiselt hane- ja hobusemaski. Praegu neid maske ei esine. Tänapäeval käiakse külades ringi peamiselt esimesel päeval - 6. jaanuaril - ja kõikjal on käibel hirmsa vožo mask (väljapoole pööratud karvaga kasukas) koos kohustusliku saua ja kotiga.

Neis külades, kus on säilinud kolme-päevase külaskäigu traditsioon, kasutatakse traditsioonilist riietust või kohandatakse tänapäevast vastavalt värvile (valge, punane, must). Märkigem, et maskeerimine on tänapäeval üks komme (välja arvatud folkloorirühmade esinemised), mil veel kasutatakse traditsioonilist riietust ja selle elemente.

Mõnevõrra teine on maskide järgnevus bessermanidel, kes elavad Tšeptsa ülemjooksul ja sealsete harujõgede ääres (Gordino ja Junda küla), kus maskeerimine algab hiljem - 13. jaanuaril. Sel päeval tulevad maskeeritud esimest korda välja ning nad kannavad valgeid riideid ja peakatteid (müts/rätik) ning maskid on tehtud valgest riidest. Teisel päeval, 14. jaanuaril käivad "ilusad vožod" punast värvi maskides, riietuses ja peakatetes. Maskide tegemiseks kasutatakse suvalisi sobivat värvi rõivaid (kleidid, mantlid), mässivad enda ümber kangatükke, linu, salle, rätikuid, kardinaid ja laudlinu. Lisaks kohustuslikule sauale ja kotile tõmbavad paljud vööle rihma või räti, rõhutades sellega riietuse arhailisust. Selles küladerühmas ilmuvad "ohtlikud/kurjad vožod"5 mitte esimesel, vaid alles kolmandal päeval - 15. jaanuaril. Nende maskid on vastavad: ümberpööratud kasukad ja tulupid, tumedad mütsid. Riietus ja näomaskid (riidest sidemed) on tumedast kangast, musta värvi. Kõikvõimalikke sotsiaal- 
olmelisi või etnilisi tüüpe (mustlased, sõdurid, kerjused) kujutavaid maske bessermanidel ei esinenud, kuid 19. sajandil ja 20. sajandi alguses hakkasid need levima udmurtide seas (Gluhhova 1999: 120) ning olid populaarsed bessermanide naabruses vene asundustes. Kommet kasutada maskide valmistamiseks vanu ja katkisi riideid ning kujutada sante bessermanidel ei esinenud ja seda ei kiidetud heaks. See on seotud mütoloogilise ettekujutusega vožodest, keda peeti mõjukateks vaimudeks ning samastati inimeste ja lahkunud esivanematega. Maskeerimisel kasutatavad maskid pidid rõhutama, et talsivaimud ja nendeks kehastunud ringkäigus osalejad on "teise maailma" asukad. Seda rõhutas ka nende tavatu käitumine, mis ei ole omane "selle maailma" asukatele.

Maskeeritute käitumine kajastab talistepühade tsükli sümboolikat, maskide ümberkehastumise ja vožodega samastumise ideed. See oluline mütoloogiline kontekst on jälgitav ka tänapäeva kombestikus. Maskeeritute maailm on vaikiv maailm, napisõnaline, ilmetu. Maskeeritud ei räägi, ei näita nägu ja püüavad jääda tundmatuks. Maski taga olevat inimest ei tohi ära tunda, maski ei tohi püüda maha võtta või selle taha piiluda:

Pererahvas tegi näo, et nad ei tunne, isegi kui nad ära tundsid. Kutsuti teiste nimedega, aga vožod pü̈̈dsid neid rohkem segadusse ajada (AVM 1990, V. M. Urasinov, Junda küla Balezino rajoon);

Nägu pü̈̈takse kinni katta, et ära ei tuntaks. Kaetakse kätega, peakattega, rätiga (AVM 1990, T. J. Kalinina, Junda Balezino rajoon);

Maskeeritud tantsivad. Näod on kaetud. Käivad vaikides, laule ei laula. Ainult koputavad keppidega ja trambivad jalgu (AVM 1991, J. J. Zjankina, Turtšino küla, Jukamenskoje rajoon);

Maskeeritute maske kergitada ja maha võtta ei tohi. See toob halba. Nad on nagu surnud inimesed. Vanaema rääkis nii ega lubanud maskeerituid ära tunda (AVM 2010, Žuvami küla, Jukamenskoje rajoon).

Tõkestatakse iga katset maski jõuga maha võtta või ära tunda, kes selle taga peitub. Mask on talsiajal samastatud vaimudega.

Majja astudes koputavad maskeeritud keppidega vastu põrandat, püüavad keppidega pererahvast puudutada, trambivad või tantsivad (jäljendavad tantsimist), käivad üksteise järel ringis:

Astuvad tuppa, teevad ringi, tantsivad ja koputavad kepiga põrandale. Pererahvas ütleb: “Jätke järele, jätke järele! Mida on, sellega kostitame” (AVM 1990. T. J. Kalinina, Junda küla Balezino rajoon). 


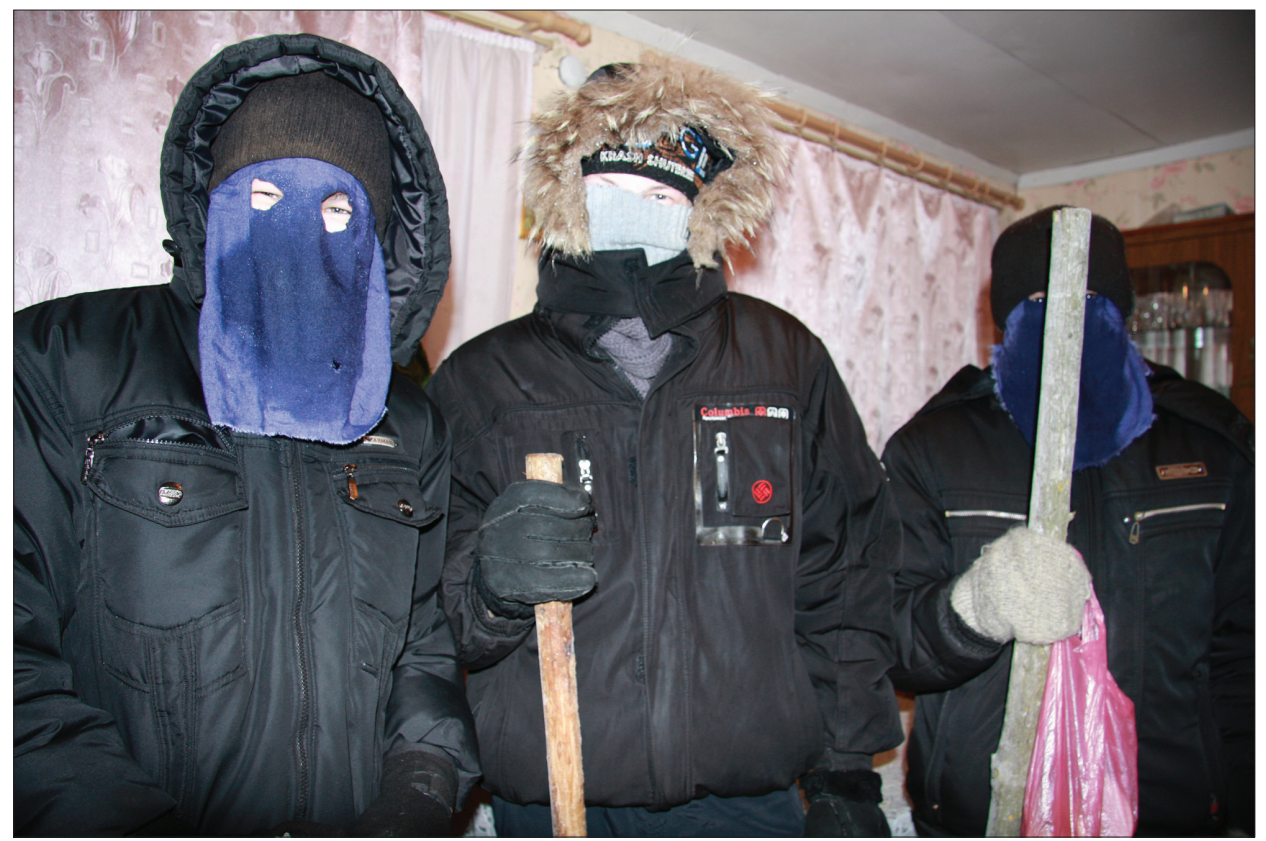

Maskeeritute ringkäik külas "koledate/ kurjade vožode" maskides. Žuvami küla, Jukamenskoje rajoon, Udmurdi Vabariik. Jelena Popova foto 2010.

Maskeeritud "hirmsa vožo" maskidega, käes kotid ja kepid. Žuvami küla, Jukamenskoje rajoon, Udmurdi Vabariik. Jelena Popova foto 2011.

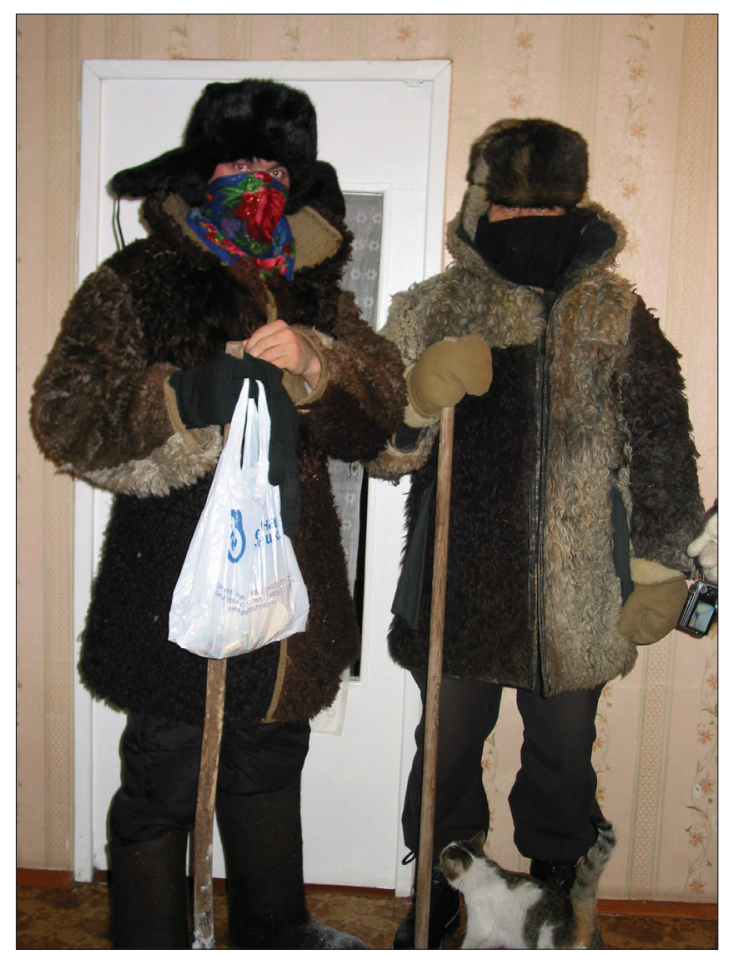




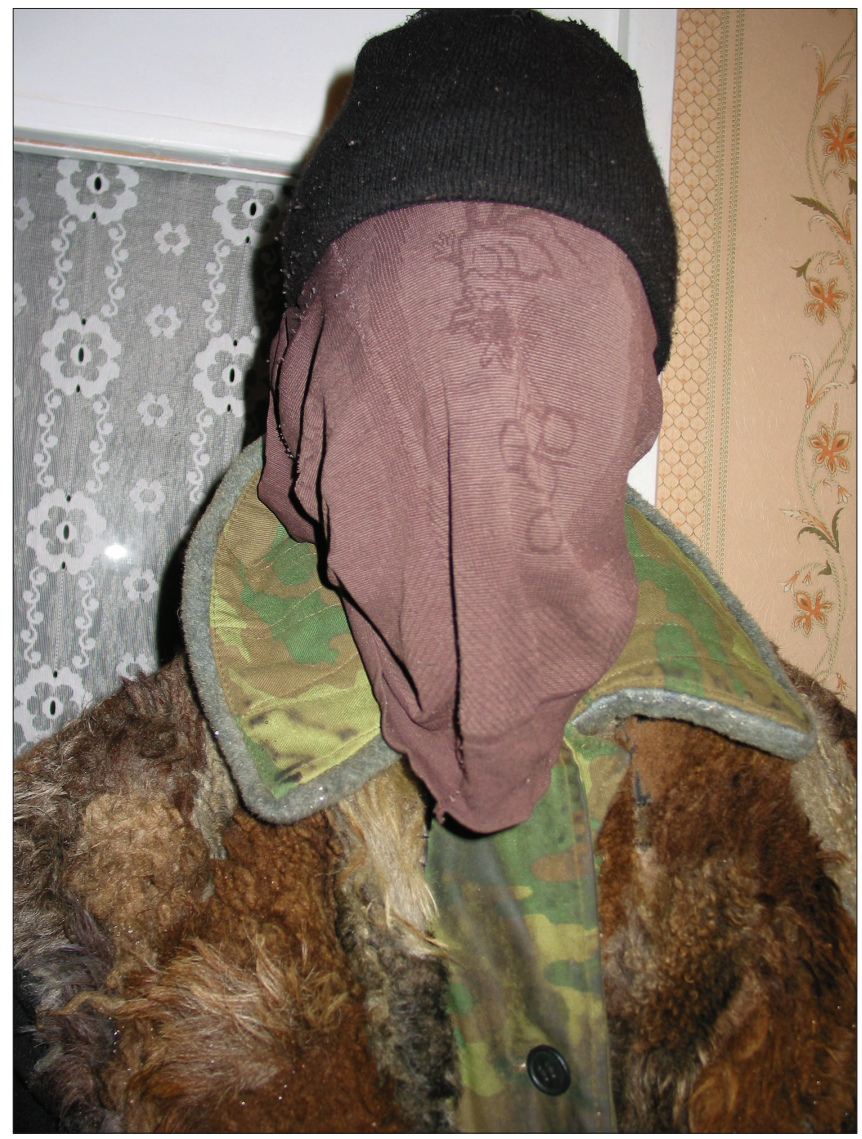

Riidest näokate - maski kohustuslik element. Žuvami küla, Jukamenskoje rajoon, Udmurdi Vabariik. Jelena Popova foto 2010.

Maskeerimine, peale vaikimise, eeldab müra (kepiga koputamine, kõva trampimine, lõõtsamäng). Need tegevused ei ole igapäevasele käitumisele omased, eriti ruumides, kuid need on lubatud maskeerunutele. Väljaspool elamuid, külatänaval liiguvad maskeeritute rühmad tavaliselt häälekalt, mõnikord saadab neid üks maskeeritu lõõtsaga. Kui moosekanti ei ole, kasutavad teismelised ja lapsed tänapäeval rahvalikke tantsulugusid, mis on salvestatud magnetofonile või isegi mobiiltelefoni (AVM 2010, Junda küla, Balezino rajoon). Üldiselt kajastas käitumine tervikuna, tänaval liikumise iseloom ja käitumine tares maskeeritute ja nende kehastuses vožo vaimude mitmetimõistetavat, mõnikord vaenulikku olemust inimeste maailma suhtes. 


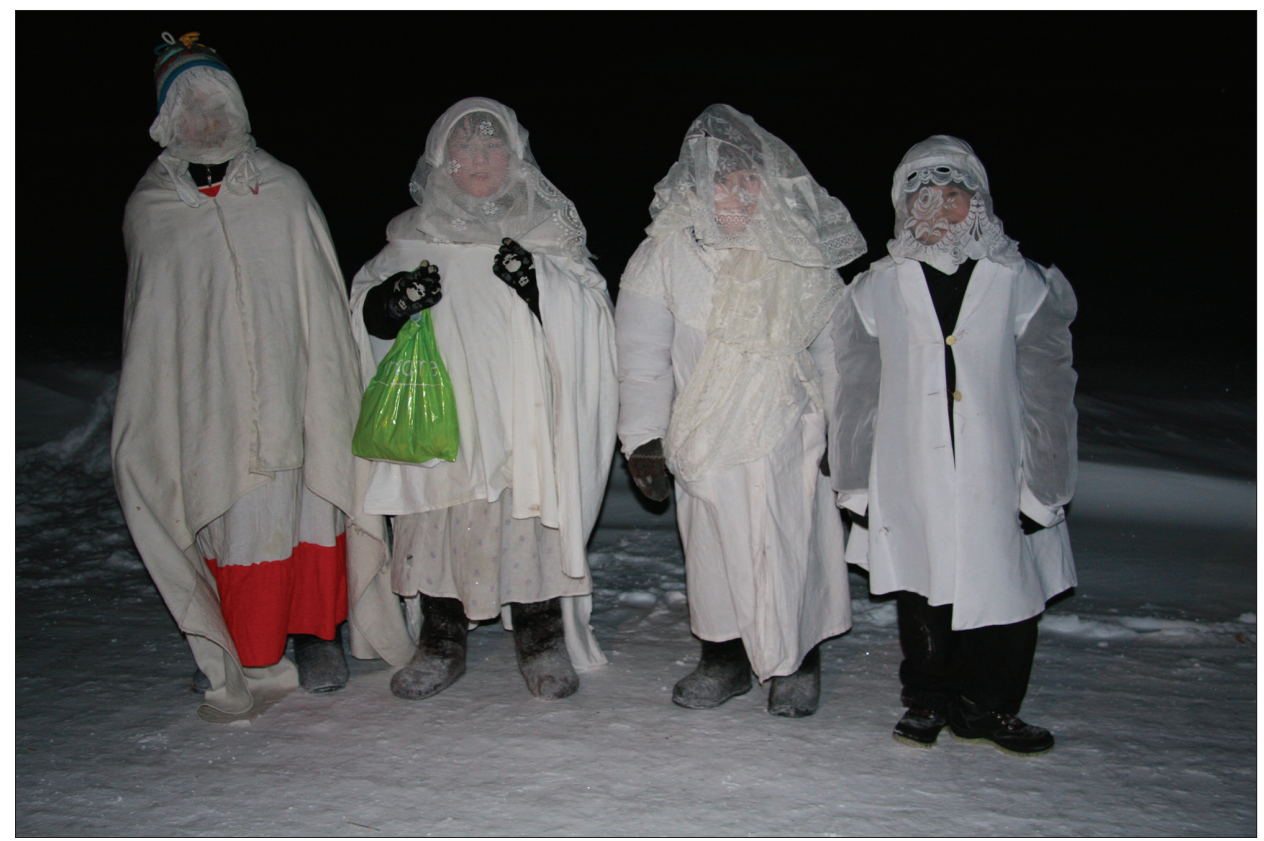

Valgesse riietatud laste ringkäik külas talistepühade esimesel päeval. "Ilusate" vožode maskid. Junda küla Balezino rajoon, Udmurdi Vabariik. Ühisekspeditsioon Venemaa Riikliku Humanitaarülikooliga (Moskva). Jelena Popova foto 2010.

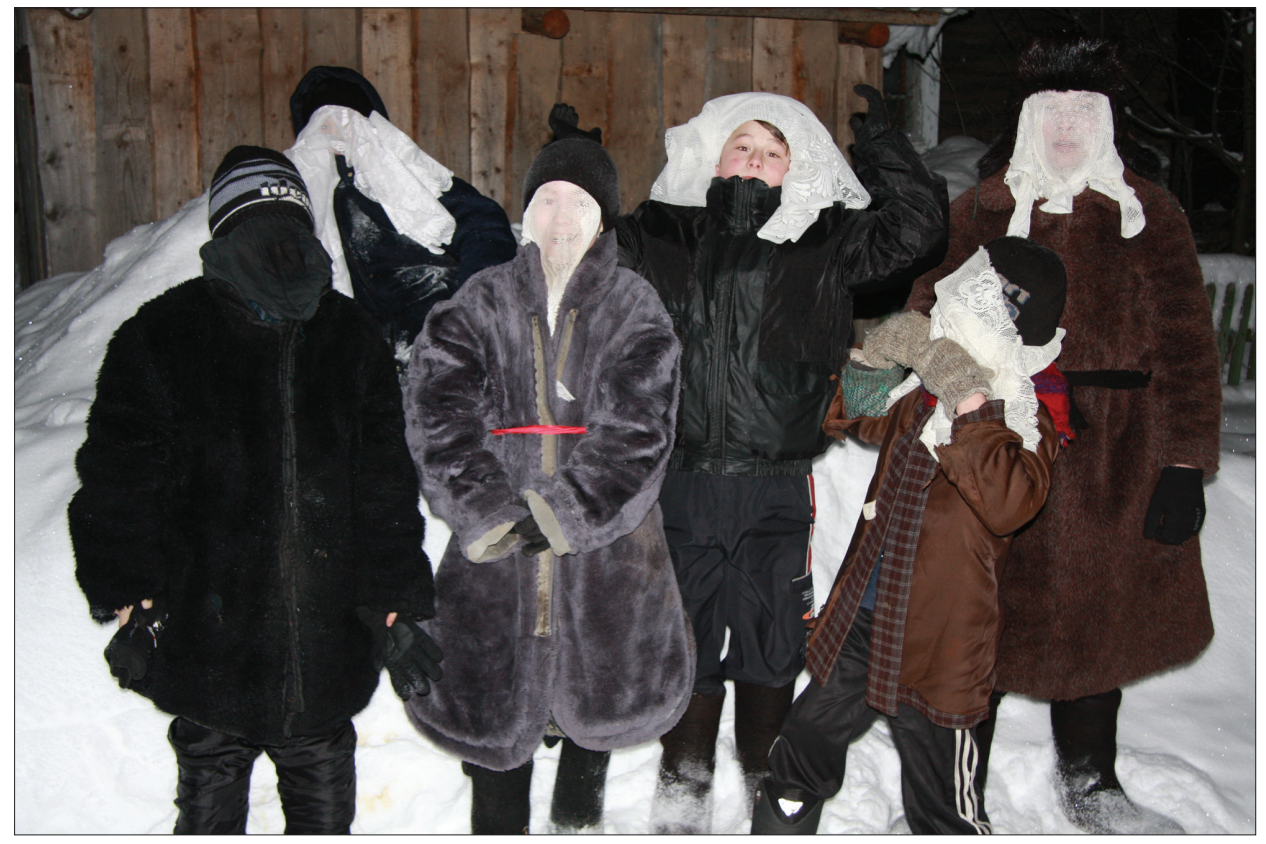

Talsipühade ringkäigus osalenud lapsed kolmandal päeval "hirmsa vožo" maskidega. Junda küla Balezino rajoon, Udmurdi Vabariik. Ühisekspeditsioon Venemaa Riikliku Humanitaarülikooliga (Moskva). Jelena Popova foto 2010. 


\section{Talistete ennustamine: traditsioonid ja uuendused}

Varem korraldas noorsugu talsiajal istumisi, täiskasvanud kogunesid üksteise poole. Tavaliselt sel ajal neil kogunemistel käsitööd ei tehtud ja neid peeti pühaks. Talsiõhtu veetmise tavaline vorm oli muinasjuttude ja lugude rääkimine, mõistatamine. Bessermanid kutsusid mõistatusi vožo kəl (вожо къл) 'vožo sõna' või 'vožo aja sõna'. Neid mõistatusi tohtis mõistatada ainult talistete ajal.

Talistete ajal, sealhulgas istjatel ka ennustati, kuid talsiennustused algasid alles 13. jaanuari õhtul. Tuleb märkida, et see ei olnud bessermanide seas levinud nähtus. Paljud vanema põlvkonna esindajad märkisid, et talistete ajal ei ennustatud üldse või ennustati vähe, ennustamise mooduseid oli vähe. Enamasti püüti ära arvata viljasaaki, kevadsuvise hooaja ilma, eelseisvat saatust (pulmi, sõjaväeteenistust, kauget teed, haigust või matuseid).

Tänapäeval on jälgitavad teised nähtused, ennustamine kuulub kaasaja kultuuri (eriti tüdrukute seas) ja seda võetakse talsiaja koostisosana. Paljud moodused on üle võetud teistest traditsioonidest, kirjasõnast, internetist, mõnikord praktiseeritakse oma kultuuri levinuimaid mooduseid. Kui varem oli ennustamine seotud eelseisva viljasaagiga, väeteenistuse, mehelemineku või naisevõtuga, siis tänapäeval on ülekaalus meelelahutusliku loomuga ennustamine "isikliku elu" küsimustes. Kasutatakse ka traditsioonilisi mooduseid. Näiteks pannakse padja alla kamm ja määratakse leitud juuksekarva järgi, milline on tulevane peigmees või pruut. Sama sihiga minnakse lauta ja püütakse lammast, selle värv määrab tulevase abikaasa omadused. Püüdes määrata tuleva aasta ilma ja viljasaaki külmutatakse lusikas veega. Kui jää tõuseb kummi, on see hea märk. Vanema põlvkonna inimesed käivad vahel harva aidas hääli kuulamas. Kui kuuldub kukkuva viljatera heli, loetakse see tuleva aasta suhtes heaks endeks, luua sahin tõotab ikaldust ja rasket aastat.

Peamiselt kuulmisaistingutel (hallutsinatsioonidel) põhinevaid traditsioonilisi ennustamisi põllul, jõe ääres või tänaval peetakse ohtlikuks ettevõtmiseks ja neid püütakse tänapäeval vältida. Seda võib seletada traditsiooni kadumisega, hirmuga rikkuda ruumilisi ja ajalisi keelde, aasta selle aja käitumisreegleid. Osaliselt on see seotud ka mütoloogiliste ettekujutuste säilitamisega, aga selle tagajärjel hirmuga rikkuda rituaalse käitumise kehtivaid keelde ja norme.

\section{Rituaalsed toidud}

Talsiaja ja maskeerimise peamiseks toidusümboliks on endiselt spetsiaalne küpsetis kvarnjanj (кварнянь), mida valmistatakse 6. jaanuari päeval. Roa nimetus tuleneb sõnadest kvar (квар) 'leht', njanj (нянь) 'leib' ja seda tõlgi- 
takse 'leib lehe kujul', ent välistatud pole ka teistsugune etümoloogia - "lehel küpsetatud leib". Seda rooga valmistatakse hapendamata taignast, segades rukkijahu (meie päevil ka nisujahu) soola ja veega. Varem lisati taignasse eraldi jahvatamata teri, läbipraetud herneid, kanepi- ja linaseemneid. Viimastel aastatel pannakse jahusse mõnikord harva läbipraetud või hoopis vastupidi leotatud herneid. Tainas rullitakse peeneks vorstiks, millest lõigatakse väikesed tükid, mis seejärel rullitakse õhukesteks 15-20 cm läbimõõduga liistakuteks ja küpsetatakse vene ahjus, kuid mitte lahtisel tulel. Valmis küpsetis määritakse või või taimerasvaga, lamba- või hanerasvaga. Seda rooga valmistatakse teiste küpsetiste, nagu leib või pirukad, kõrval.

Sotšnisid peetakse talsiaja kohustuslikuks roaks, nendega kostitatakse maskeerituid. Viimastel aastatel on nende kõrval hakatud jagama ka muid küpsetisi, ostetud maiustusi - küpsised, präänikud, kommid:

Neile [maskeeritutele] varem maiustusi ei jagatud. Anti sotšneid. Küpsetati kanepiga. Kui küpsetati ka pirukaid [šangi - lahtised pirukad] ja leiba, anti ka pirukaid (AVM 1996, A. D. Sabrekova, Glazovi linn).

Täiskasvanuid kostitatakse mõnikord lisaks leivale ka alkoholiga.

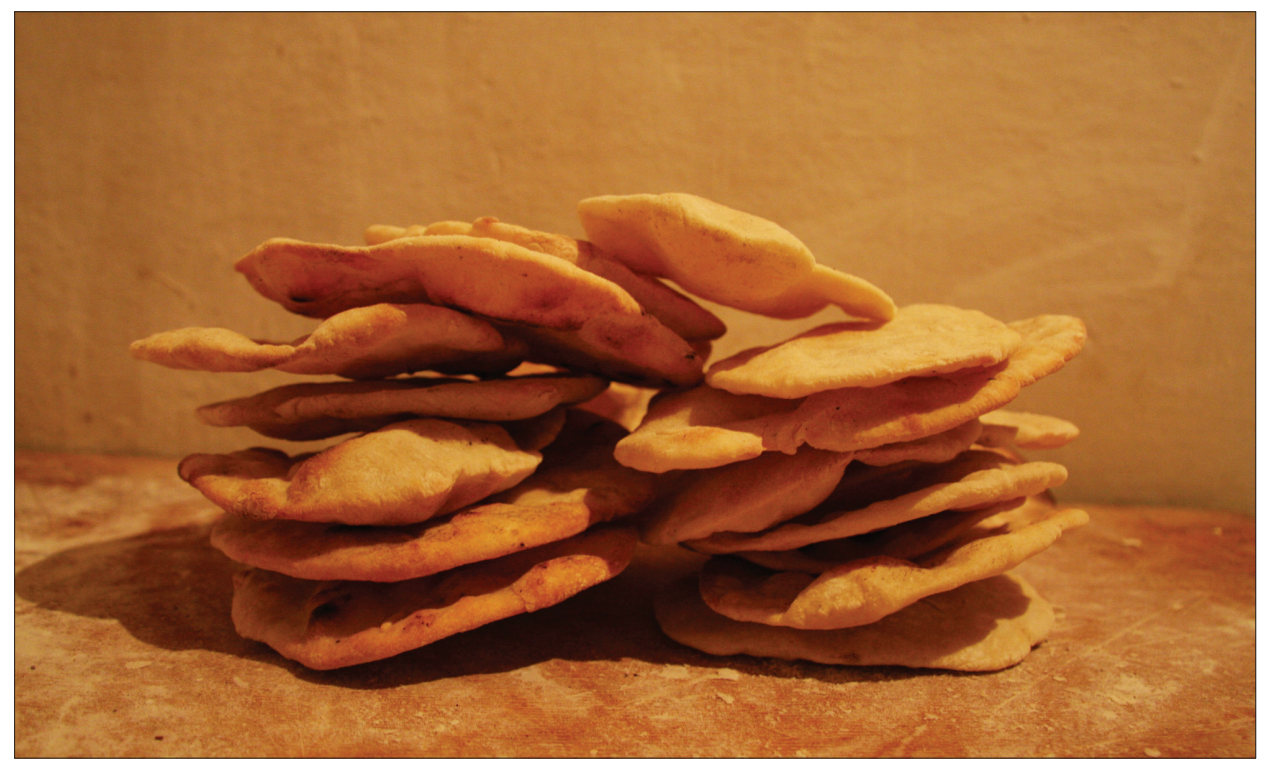

Talsiaja küpsetis - sotšni hapendamata taignast. Žuvami küla, Jukamenskoje rajoon, Udmurdi Vabariik. Jelena Popova foto 2010. 


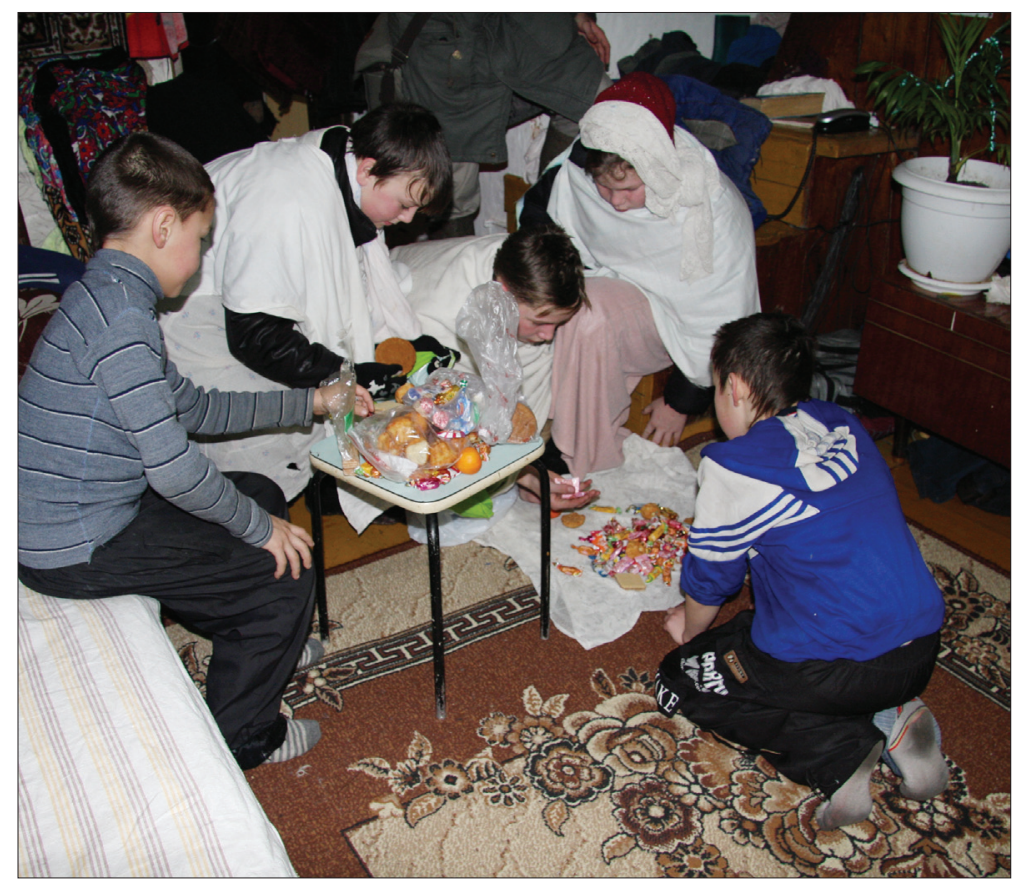

Talsipühade ringkäigus osalenud lapsed jagavad esimesel ringkäigu päeval kogutud kingitusi. Junda küla Balezino rajoon, Udmurdi Vabariik. Ühisekspeditsioon Venemaa Riikliku Humanitaarülikooliga (Moskva). Jelena Popova foto 2010.

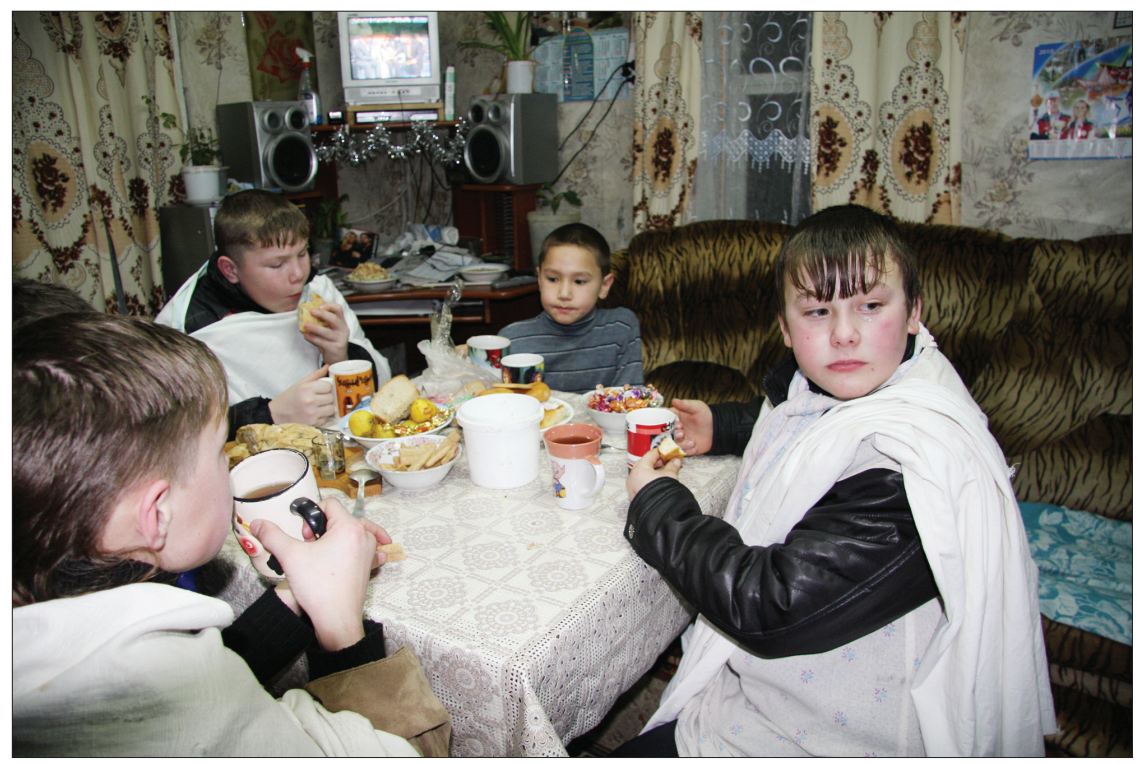

Laste ühine söömaaeg pärast külas ringikäimist. Junda küla Balezino rajoon, Udmurdi Vabariik. Ühisekspeditsioon Venemaa Riikliku Humanitaarülikooliga (Moskva). Jelena Popova foto 2010. 
Sotšnite ja leiva valmistamist ning nendega kostitamist peetakse maaviljeluse edu aluseks, hea viljasaagi ja õnne tagatiseks. Seda toetavad ka maskeeritute ja pererahva vastastikused soovid:

Sel päeval küpsetati sotšnisid [сочни] ja jagati neid, mõned andsid komme, präänikuid ja leiba. Vožo tänab neid: “Aitäh. Las vili kasvab” (AVM 1996, A. D. Sabrekov, Glazovi linn).

Paraku on nende väljaütlemiste semantiline väli viimasel ajal ahenenud. Räägitakse karja juurdekasvust, aiaviljade saagist, heaolust ja tervisest:

Kõike head teile. Mitte kunagi põdeda. Et kogu aeg oleks kodus edu. Et pension oleks tulevikus hea. Et raha oleks palju. Et kari kasvaks suureks. Et lapsed kasvaksid suureks.

Et oleks armastus, soojus ja rõõm. Palju raha (AVM 2010, Junda küla, Balezino rajoon).

Varem populaarseid vilja- ja linasaagi soove võib kohata üha harvem, sest neid kultuure tänapäeva kodumajapidamistes enam ei kasvatata. Kui sellised soovid ka kõlavad, siis üksnes selleks, et rõhutada traditsiooni arhailisust ja toetada maskeerijate mängu. Täheldatavad on ka sisulised uuendused, näiteks tänapäeval aktuaalsed soovid "välja teenida suur pension", "saada suuremat palka", "lastel ja lastelastel hästi õppida", "rohkem lapsi peresse", "leida tööd" (AVM 2010, Junda küla, Balezino rajoon).

Omaküla elanikelt saadud leib ja kostitused loetakse olevat maskeeritute endi viljasaagi ja heaolu tagatis, osa toiduainetest söödetakse loomadele. Kui maskeeritud käivad rühmiti, jagatakse saadud külakost omavahel ära. Näiteks Junda külas kogunevad lapsed pärast ringkäiku külas järgemööda (kolm õhtut) ühe maskeerimises osalenu koju, kus vanemad katavad kogu seltskonnale peolaua. Pärast ühist pidusööki jagavad lapsed omavahel saadud kosti (AVM 2010, Junda küla, Balezino rajoon). Üldjoontes koorub välja kostituste ja soovide semantika - üks olulisemaid ja püsivamaid jooni, mis iseloomustab mitte üksnes tänapäeva kombe agraarset suunda, vaid märgib ka praeguse aja erijooni.

\section{Talsiaja vaimude vožode "ärasaatmise" kombestik}

Talsipühade aeg lõpeb spetsiaalse söömaaja ja vožo "ärasaatmisega" vožo keljan (вожо кэлян), supiga vоžо šõd (вожо шьљ, 'supp vožole') või supiga vožo ärasaatmise puhul (вожо келян шод), mis korraldatakse kolmekuningapäeval. Piduliku söömaaja ja toitude valmistamise peamine eesmärk on saata austuse ja kostitustega ära talsivaimud "kui tähtsad ja auväärsed külalised”, lõpetada 
see oluline kalendritsükkel. Kolmekuningapäeva (Крещенья) nimetatakse ka vožo ärasaatmise päevaks, jää peal seismiseks. Viimane termin tuleneb bessermanide kombest pühitseda pühakojas vett ja looduslikke veekogusid, mida suures osas käsitleti talsivaimudega hüvastijätmise aktina.

Talsivaimude ärasaatmise kombestikus on oluline koht kohalikel jõgedel ning asustuse paiknemisel allikate ja jõesuudmete, alam- ja ülemjooksude suhtes. Alguses saadeti vaime ära asulates, mis asusid jõgede ülemjooksul, seejärel "vožod laskusid" alamjooksule. Näiteks kui jõe ülemjooksul elavatel bessermanidel oli kombeks vožoga hüvastijätt 18. jaanuaril, peeti alamjooksul söömaaega ja korraldati ärasaatmisrituaal alles järgmisel päeval. Sellepärast ei tohtinud ööl vastu 19. jaanuari olla väljas ja lärmata jõe ääres rituaali juba korraldanud külast allavoolu asuvates külades. Need keelud olid seotud ettekujutusega, et jõe ülemjooksul "saadeti vožod ära ning nad jätkavad teed ja külastavad allavoolu asuvaid külasid”. Siin on säilinud jõe ülem-ja alamjooksu semantiline tähendus:

Vožod lähevad talvel ja suvel jõkke. Talvel kolmekuningapäeval (AVM 1999, A. I. Bijanova, Korotai küla, Glazovo rajoon).

Möldrid avasid varem tamme spetsiaalselt selleks, et vožod saaksid takistamatult ära minna, samal põhjusel keelati allavoolu jõge ületada või selle läheduses asuda:

Öeldakse, et vožod tulevad jõejää alt. Räägiti, et kellegi külaelanikest olevat endaga jää alla viinud (AVM 1991, V. M. Sabrekov, Šamardani küla, Jukamenskoje rajoon).

“Vožode ärasaatmist” korraldati perekondliku söömaaja ja seejärel kõigi majapidamiste ühise pidusöögiga. See komme oli alles veel 20. sajandi keskel. Tänapäeval on söömaaeg ja kogu rituaal suures osas taandunud pereringi. Küla ühiseks lauakatmiseks koguti varem tangu ja liha, mida väikeses koguses tõi iga perekond. See oli ühise rituaalse roa valmistamise tähtis tingimus. Igaüks "osales" sel moel toidu valmistamises ja putru valmistati kõigi külaelanike nimel. Toitu tehti ja pidulaud korraldati spetsiaalses tares - vožode ärasaatmise majas (вожо корка), majas, kus saadetakse vоžоsid (вожо кэлян корка), mis asus küla lõpus kõige lähemal taliviljapõllule. Peamine rituaalne roog oli lihapuljongis (soovitavalt hanepuljong) keedetud odratangu puder. Putru keedeti sel õhtul ka igas peres. Alguses istuti laua taga pereringis, külastati sugulasi, võeti ise külalisi vastu.

Pärast koduse ringi kombetäitmist ja vožodega hüvasti jätmist kogunesid iga majapidamise esindajad majja, kus toimus ühine söömaaeg ja ärasaatmine. Rituaalse peolaua ja ärasaatmise etikett oli sama nagu oli olnud koduses ringis. Alguses paluti laua äärde talsivaimud vožod ja prooviti ohvriputru. Seejärel 
suunduti osa toidu ja jookidega ühe või mitme vankriga (ekipaaže pidi olema paaritu arv) küla taha "vožo vaime ära saatma":

Vožosid saadetakse nagu külalisi, kellukestega. Õhtul viiakse nad külast välja (AVM 1990, N. K. Nevostrujeva, Žuvami küla, Jukamenskoje rajoon).

Kogu etikett, jututeemad ning kombetalituse ja söömaaja osaliste käitumine rõhutasid, et "talsivaimud on kohal nagu külalised", "neid saadetakse ära kostituste ja austusega". Nende poole pöördutakse väljendustega "kallid", "kuldsed", "austatud" külalised. Sellist häälestust hoitakse ka nüüdisajal selle päeva perekondlikel laua ääres istumistel, see oli täheldatav ka neil söömaaegadel, kus mul õnnestus osaleda välitööde käigus. Osa neist korraldati pereringis (AVM 1994, Šamardani küla), teised koduste ja kollektiivsete söömaaegadena ja ärasaatmiskombestikuga (AVM 2010, Junda küla, Balezino rajoon). Selle päeva õhtuks keedetakse igas peres endiselt lihapuljongiga putru, millel on oma nimi - "vožode ärasaatmise puder". Mõnes külas oli eriline kostitamise viis, mida võib praegugi kohata vanemate inimeste seas. Näiteks keerati puder traditsioonilistesse pliinidesse niimoodi, et selle välimus meenutaks rege, millega vožod “ära sõitsid” (AVM 1999, Korotai, Bõdzemšuri, Gordino küla). Sel päeval köetakse jälle sauna, et "vožod enne teeleasumist peseksid ja läheksid ära heaga".

Tänapäeval täidetakse kommet üksnes pereringis. Hämaruse saabudes kaetakse laud, kuhu pannakse eraldi taldrik pudruga, kali või muu jook, pannakse lusikas: "vaat, vožod hakkavad sööma", "vožod on külas", "nad on meiega laua taga". Pere vanim liige jätab nendega hüvasti, pöördudes nende poole kõigi kohalolijate nimel: "Saadame vožosid. Te ei jäta meid igaveseks. Suvel tulete tagasi” (AVM 1994, K. I. Karavajeva, Šamardani küla, Jukamenskoje rajoon). Päris õhtusöögi alguses lähevad mitu inimest (neid peab olema paaritu arv) eesotsas pere vanima inimesega ohverduspudru taldrikuga, joogi ja leivaga "vožosid saatma". Nad lähevad jõe poole, kus panevad kaldale, spetsiaalselt raiutud jääauku või põllul lumele (mõned endast vasakule) toidupalukesi, leiba ja kallavad jooki (AVM 1994, Šamardani küla; AVM 2009, Jukamenskoje rajoonis Ježevo (udm Jožgurt) asula, Ust-Lemi küla; Jari rajoonis Vortsa küla; AVM 2010, Junda küla). Mõnes külas on säilinud komme süüdata jõe jääl või kaldal kolm peergu või õletuust. Mõnikord torgatakse peerud lihtsalt lumme seal, kuhu jäetakse rituaalset toitu: väljaspool küla jõe suunal (Šamardani küla). Mitmes asulas piirdutakse tänapäeval üksnes pudrukeetmisega, pereringi söömaajaga, mille jooksul jäetakse vožo vaimudega hüvasti, kuid ei saadeta neid enam küla taha.

Kombetalitust saatvad tekstid koosnevad lühivormelitest: "Minge heaga. Andke head elujõudu. Las vili kasvab hästi” (AVM 1996, A. D. Sabrekova); 
"Minge heaga. Vožosid saadame. Las nad annavad meile aasta head elu" (AVM 1991, J. J. Zjankina, Turtšino küla, Jukamenskoje rajoon). Eriline tähendus jõulukombestiku soovides ja tegevustes on endiselt üleminekut, uuenemist ja uue aastatsükli algust märkival semantikal.

Pärast perekondlikku söömaaega korraldatakse tänapäeval mõnes asulas ühislaud klubis, kust kõik suunduvad koos laulude ja lõõtsamuusikaga jõe äärde talsivaime "ära saatma". See kõik kujutab endast aastaid kestvat katkematut traditsiooni, ühte ühiskondlikku piduliku jõudehetke kultuuriilmingut, mitte lavalist rekonstruktsiooni (Vortsa küla). Mul oli võimalus osaleda ka sellises ärasaatmiskombestikus, mis toimus kitsas ringis perekondliku einena (Šamardani ja Žuvami küla), kus laual oli puder, leib, kali ja tee, millele järgnes hüvastijätt vožodega jõe ääres; teisalt osalesin ühiskondlikus ärasaatmises, mille olid korraldanud klubi- ja muuseumitöötajad (Junda küla). Viimasel juhul on komme säilitanud kõik kohustuslikud elemendid ja selle taassünd küla peokultuuri osana on saanud teoks tänu vanemale põlvkonnale, kes on saanud osa veel elavast kultuurist ning teavad üsna hästi traditsioonilise kombestiku struktuuri (AVM 2010, Junda küla). Nii osalejad kui ka korraldajad suhtusid sündmusse äärmise tõsidusega. See puudutas tekste, rituaalseid toite, osalejate liikumist ja tegevust asula sakraalsel maastikul (põld, jõgi). Kombetalituses osalejad palusid vožo vaimudelt andestust, kui ei ole teadmatusest, nooruse tõttu või kogenud vanarahva puudumisel osanud arvestada traditsiooni kõigi detailidega. Tuleb märkida, et selline palve on kombestiku väga hea tundmise juureski paljude tekstide oluline eripära, mis väljendab külalislahkuse ja rituaalse etiketi osana viisakust.

Tänapäevane vožode ärasaatmise kombestik sisaldab osaliste väljasõitu reel lõõtsa saatel lähima jõe äärde. Selle järel korraldatakse kogu rituaalne tegevus ja "hüvastijätt" jõe kaldal. Alguses raiuti siin jäässe auk, jäeti vožo vaimudega hüvasti, poetati jääauku lusikatäis putru, veidi leiba, kallati sinna jooke, kusjuures kõik juuresolijad proovisid ka igast roast natuke. Hüvastijätu tekst, mis vožode poole pöördudes ette kanti, oli traditsiooniliste vormelitega improvisatsioon. Tekst kantakse ette jõe ja jääaugu poole pöördunult:

Andke head. Minge oma maailma. Andke meile kõike head. Jätke siia kõik hea. Las halb läheb meist kõrvalt mööda. Talisteid ja vožo [vaime] tuleb meil tulevikus jälle vastu võtta ja võõrustada. Samasuguste kaetud laudadega, hea tujuga, heade inimestega ja tervisega. Las vili võrsub ja kari kasvab. Las kõik läheb hästi. Viige kõik paha endaga kaasa. Hea jätke meile. Tuleval aastal tulge uuesti heaga. Tooge üksnes head elu. Las vili võrsub ja kari sünnib. Olgu kõik hästi (AVM 2010, Junda küla).

Seejärel süüdati jääaugu juures õlekimp ja sooritati jõel vožode "ärasaatmise" tseremoonia. 


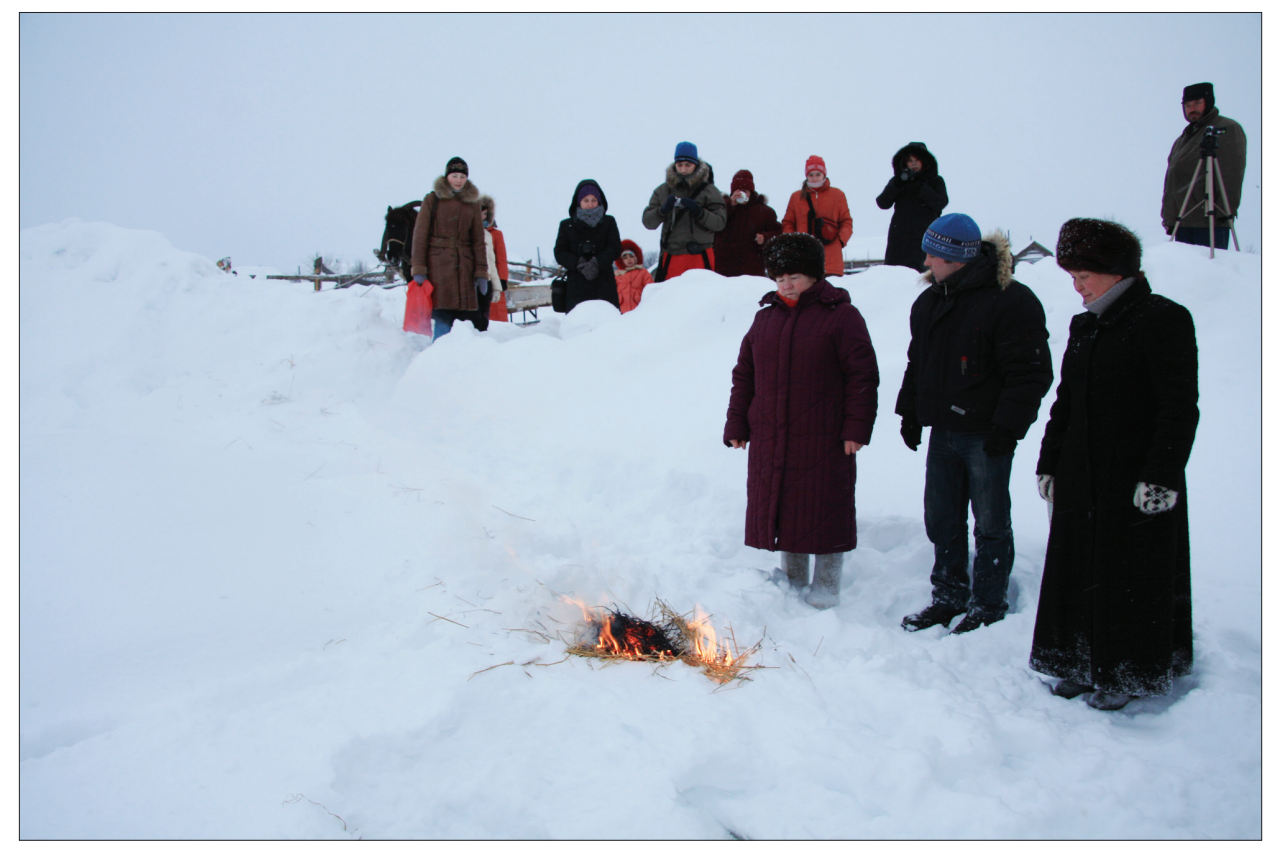

Vožode ärasaatmine jõe ääres. Junda küla Balezino rajoon, Udmurdi Vabariik. Jelena Popova foto 2010.

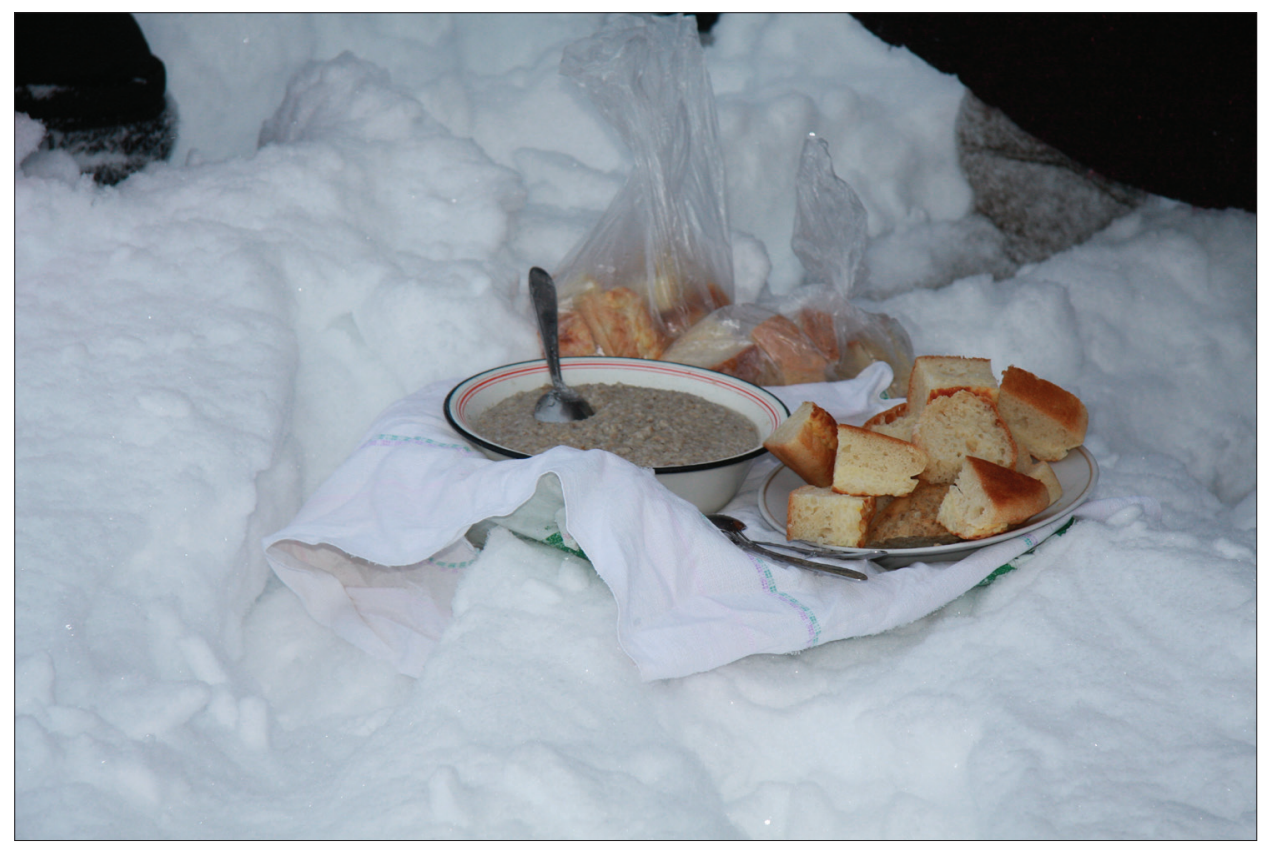

Rituaalsed toidud, mis on mõeldud talsivaimude (vožode) ärasaatmiseks jõe ääres. Junda küla Balezino rajoon, Udmurdi Vabariik. Ühisekspeditsioon Venemaa Riikliku Humanitaarülikooliga (Moskva). Jelena Popova foto 2010. 
Järgnes tegevus põllul, kuhu suundus protsessioon. Ent vahetult osales tseremoonias piiratud arv inimesi. Siin jäeti toiduained (puder, munad, leib) maapinnale ja kaeti lumega ning pöörduti juba maa peremehe Muzjemkuzjo (Музъелкузё) poole, mida rõhutas omakorda tekst:

Las annab meile elus kõike head. Las tuleb hea viljasaak ja kari las kasvab. Las lapsed kasvavad hästi. Las pered elavad üksmeeles. Las inimesed elada üksmeeles. Las kõik läheb hästi. Kõigile tervist. Et me elaksime kauem sõbralikus peres rahuliku taeva all. Sõbralikus rahvaste peres. Las võtab [maa peremees] vastu, las võtab (AVM 2010, Junda).

Sellest kombest osavõtnute (kolm naist) teatel osalesid selles tseremoonias varem ainult vanurid, kes siirdusid põllule paarituarvulise seltskonnana.

Meie päevil naastakse pärast vajalikke toiminguid jõe ääres ja põllul külla, kus korraldatakse ühissöömaaeg klubis või küla muuseumis. On tähelepanuväärne, et samas külas on säilinud "vožode ärasaatmise" komme ka pereringis. Ôhtul pimeduse saabudes, kuid mitte hiljem kui kell kaheksa või üheksa, pärast seda, kui tares on kaetud laud, läheb keegi pererahvast (täiskasvanud pereliige) jõe äärde ja jätab kaldale või jääauku leiva, pudru ja joogid. Selliselt vožo vaime järgmise kalendritsüklini ära saates viib ta kombetalituse lõpule. Arvatakse, et sellest ajast alates lahkuvad vožod lõplikult külast ja sellest maailmast.

Nagu näeme, on vožodega seotud talsikombestik vaatamata rahvakalendri muutumisele säilitanud ka tänapäeval agraarse suuna ja ettekujutused, esivanemate kultuse austamise, teispoolse maailma vastastikuse tegevusega, maskeerumise, maskide ja rituaalse köögi abil ümberkehastumise ideega. Selles on jälgitav aasta jagunemine kaheks oluliseks perioodiks ja nende vastastikune mõju. See on üks väheseid kombeid, mis on säilinud hoolimata kalendri ja selle struktuuri ning traditsiooniliste ettekujutuste vahetumisele. Viimastel aastatel on täheldatav kombestiku ja selle elementide juurdumine tänapäevasesse pühadekultuuri. Kuid siin on täheldatav mõningate protsesside paralleelne areng: arhailiste elementide olemasolu ja loomulik areng, nüüdiskultuuri aktiivne mõju. Kombestiku järgimine on vaadeldav traditsiooni järjepidevusena ja seda peetakse tänapäevase etnilise kultuuri oluliseks koostisosaks.

Tõlkinud Asta Niinemets 


\section{Kommentaarid}

1 Terminid vožo/vožojaskon (вожо/вожояськон) esinevad udmurtide põhjapoolseltel asualadel ja tähendavad, nagu bessermanidelgi, maskeerimisaega, suvist ja talvist pööripäeva, talsivaime. Kõigi terminite tüvi on vožo. Selle etümoloogia teoreetilisi küsimusi ja probleeme on korduvalt käsitletud udmurdi etnograafias ja folkloristikas (Vladõkin 1994: 226-230; Vladõkina 1998: 84; Pletneva 1999: 245-249; Gluhhova 2009: 45-48). 19. sajandi ja 20. sajandi alguse teadlased kasutasid seda terminit korduvalt. Osa arvas, et see pärineb tüvest vož (вож) 'roheline, noor' ja seostas selle varem austatud vaimu/jumalusega, oletades, et "jumaluse nimi on säilinud üksnes aja tähistusena - vоžo dõr (вожо дыр) (Pervuhhin 1888, 1: 58). Põhjapoolsed udmurdid teavad ajavahemikku 20. juunist 1 . juulini ja 25. detsembrist 6 . jaanuarini rohelise ajana (vožo dõr) (Gavrilov 1880: 159). See arvati pärinevat sõnast "roheline", mis on omandanud tähenduse "räpased vaimud", kes aktiviseeruvad kaks korda aastas suvel rukki õitsemise ajal invožo dõr (инвожо дыıр) ja talvel talsipühade ajal vožo dõr (вожо дыр) (Vereštšagin 1998, 3, 1: 233). Lähedase etümoloogia omistas terminile ka vene etnograaf Dmitri Zelenin: "Vožo on vaim, kes tundub ebausklikule bessermanile justkui talsiaja peremehena [---] talsiaega nimetavad nad oma keeles "roheliseks ajaks" (Zelenin 1910: 117). Nüüdisaegsetes käsitlustes arvatakse termin vožo pärinevat ühispermikeelsest sõnast veža 'püha, õnnistatud, pühitsetud', aga ajavahemik vežadõr, vоžodõr (вежадыр, вожодыр) tähendas algselt keelatud, tabulist aega, mil ei tohtinud teha teatud töid (Lõtkin \& Guljajev 1999: 50; Perevoztšikova 1982: 9).

2 See traditsioon on kujunenud Tšeptsa (Vjatka harujõgi) keskjooksu lisajõgede Lekma, Lema ja Ubõti äärsetes kompaktses asundustes ning praeguse Udmurdi Vabariigi Jukamenskoje ja Jari rajoonis.

3 13.-18. jaanuarini maskeerimine on kombeks Tšeptsa ülemjooksu lisajõgede külades (Junda, Gordino, Gurzi, Kuregovo (udm Kureggurt), Bõdzemšur) - tänapäeva Udmurdi Vabariigi Balezino rajoonis. Selle traditsioon on säilinud tänaseks olemast lakanud perspektiivituks tunnistatud küladest lähedastesse udmurdi või bessermani küladesse ümberasunute seas. Sellised tähistamise ajad kehtivad ka mõnes selle piirkonna põhjaudmurtide külas.

4 Seda traditsiooni on täheldatud Udmurdi Vabariigi Jukamenskoje ja Jari rajooni bessermanide puhul.

5 Maskeeritute ja vožo vaimude jagunemisel "ohtlikeks/kurjadeks" ja "ilusateks" sõltuvalt talsiaja päevadest (esimene/viimane talsivaimude käimise päev, nendega kohtumine või hüvastijätt) leidub paralleele ka teistes kultuurides. Näiteks on see lähedane vene ja üldslaavi traditsioonile, kus on täheldatav maskeeritute jagunemine sõltuvalt talsiajast koledateks, ilusateks ja pühadeks.

\section{Allikad}

$\mathrm{AVM}=$ autori välitöömaterjalid autori valduses . 


\section{Kirjandus}

Gavrilov, Boris 1880. Proizvedeniia narodnoi slovesnosti, obriady i pover'ia votiakov Kazanskoi i Viatskoi gubernii. Kazan'.

Gluhhova, Galina 999. Rites de passages Udmurtskogo obriadovogo kalendaria. Tarakanov, I. V. \& Kel'makov V. K. (koost). Problemy udmurtskoi i finno-ugorskoi filologii: Mezhvuzovskii sbornik nauchnykh trudov. Izhevsk: Izdatel'stvo Udmurtskogo universiteta, lk 117-124.

Gluhhova, Galina 2001. Riazhen'e: mir zvuchashchii i bezmolvnyi. Vladõkina, Tatjana (vast toim). Finno-ugorskaia fol'kloristika na poroge novogo tysiacheletiia. Izhevsk: Udmurtskii institut istorii, iazyka i literatury Ural'skogo otdeleniia Rossiiskoi akademii nauk, lk 46-54.

Gluhhova, Galina 2009. Terminologiia udmurtskogo riazhen'ia. Traditsionnaia kul'turav izmeniaiushchemsia mire: Materialy XVIII Mezhdunarodnoi shkoly molodogo fol'klorista "Traditsionnaia kul'tura v izmeniaiushchemsia mire' i seminara "Permistika: iazyk i stil' fol'klora" (Izhevsk, 19-21 iiunia, 12-13, 15 noiabria 2009 g.). Izhevsk: Udmurtskii institut istorii, iazyka i literatury Ural'skogo otdeleniia Rossiiskoi akademii nauk, lk 45-48.

Zelenin, Dmitrii 1910. Gde prazdnuiut sviatki dvazhdy v godu? Priroda i liudi 8, lk 117.

Ivleva, L[arisa] 1994. Riazhen'e v russkoi traditsionnoi kul'ture. Sankt-Peterburg: Rossiiskii institut istorii iskusstva.

Korepova, Klara E 2009. Russkie kalendarnye obriady i prazdniki Nizhegorodskogo Povolzh’ia. Sankt-Peterburg: Tropa Troianova.

Lõtkin, Vassili \& Guljajev, Jevgeni 1999. Kratkii etimologicheskii slovar' komi iazyka. Syktyvkar: Komi knizhnoe izdatel'stvo.

Perevoztšikova, Tatjana 1982. Ob udmurtskoi narodnoi zagadke. Perevoztšikova, Tatjana (koost). Zagadki=Madis'kones. Izhevsk: Udmurtiia.

Pervuhhin, Nikolai 1888. Eskizy predanii i byta inorodtsev Glazovskogo uezda. Drevniaia religiia votiakov po ee sledam v sovremennykh predaniiakh. Eskiz I. Viatka: Izdatel'stvo Gubernskogo Statisticheskogo komiteta.

Pletneva, Irina 1999. K semantike udmurtskogo vozho. Tarakanov, I. V. \& Kel'makov V. K. (koost). Problemy udmurtskoi i finno-ugorskoi filologii: Mezhvuzovskii sbornik nauchnykh trudov. Izhevsk: Izdatel'stvo Udmurtskogo universiteta, lk 245-249.

Popova, Jelena 2004. Kalendarnye obriady besermian. Izhevsk: Udmurtskii institut istorii, iazyka i literatury Ural'skogo otdeleniia Rossiiskoi akademii nauk.

Rahvuslik koosseis 2004 = Natsional'nyi sostav 2004 - Natsional'nyi sostav $i$ vladenie iazykami, grazhdanstvo. Moskva: IITs "Statistika Rossii" (Itogi Vserossiiskoi perepisi naseleniia 2002 g.: 14 köites. Federeral'naia sluzhba gosudarstvennoi statistiki). 4. kd, 1. rmt. Tabel 1. 
Tšernõhh, Aleksandr 2007. Russkii narodnyi kalendar'v Prikam'e. Prazdniki i obriady kontsa XIX serediny XX v. Ch. 2 Zima. Perm': Pushka.

Vereštšagin, Grigorii 1998. Starye obychai i verovaniia votiakov Glazovskogo uezda. Vereštšagin, Grigorii. Sobranie sochinenii 3. köide 1. raamat. Izhevsk: Udmurtskii institut istorii, iazyka i literatury Ural'skogo otdeleniia Rossiiskoi akademii nauk, lk 206-239.

Vinogradova, Ljudmila 1982. Zimniaia kalendarnaia poeziia zapadnykh $i$ vostochnykh slavian: Genezis i tipologiia koliadovaniia. Moskva: Izdatel'stvo Nauka.

Vinogradova, Ljudmila \& Plotnikova, Anna 2009. Rozhdestvo. Tolstoi, Nikolai (toim). Slavianskie drevnosti: etnolingvisticheskii slovar' 4: P (Pereprava cherez reku) - S (Sito). Moskva: Mezhdunarodnye otnosheniia, lk 454-460.

Vladõkin, Vladimir 1994. Religiozno-mifologicheskaia kartina mira udmurtov. Izhevsk: Udmurtiia.

Vladõkin, Vladimir \& Perevoztšikova, Tatjana 1990. Godovoi obriadovyi tsikl udmurtskoi obshchiny "buskel" (Materialy k narodnomu kalendariu). Spetsifika zhanrov udmurtskogo fol'klora. Izhevsk: Udmurtskii institut istorii, iazyka i literatury Ural'skogo otdeleniia Rossiiskoi akademii nauk, lk 44-95.

Vladõkina, Tatjana 1998. Udmurtskii fol'klor: problemy zhanrovoi evoliutsii $i$ sistematiki. Izhevsk: Udmurtskii institut istorii, iazyka i literatury Ural'skogo otdeleniia Rossiiskoi akademii nauk. 


\section{Summary}

\section{Mumming and Masking at Christmas in Bessermens' Calendar Customs of Today}

Jelena Popova

Keywords: Bessermens, customs related to talsipühad, masking, ritual feasts and foods, traditions and innovations

The article gives an overview of the current customs and masking in the ethnic group of Bessermens at talsipühad (old name for Christmas). The author discusses the changes that have taken place in masking traditions as well as the importance of rituals in today's village community. Attention is focused on mythological images of talsi spirits, restrictions related to space and time, preferences during holidays, peculiarities of masking, ritual cuisine and etiquette. In recent years the traditional customs and their elements have started to take root in today's holiday culture; yet, a parallel development of some processes can be observed here: modern culture actively influences the archaic elements and their evolution. 